\title{
Vascular reparation training program in experimental model for general surgery residents
}

\author{
Programa de entrenamiento en reparacion vascular en modelo experimental para \\ residentes de cirugía general
}

\author{
Miguel A. Sierra-Juárez", Christian I. Cruz-Romero*, Ansony R. Godinez Vida² and \\ Marco A. Durán-Padilla ${ }^{3}$
}

${ }^{1}$ Department of Angiology and Vascular Surgery; ${ }^{2}$ General Surgery; ${ }^{3}$ Pathology Department. Hospital General de México Dr. Eduardo Liceaga, Mexico City, Mexico

\begin{abstract}
Introduction: Simulated training programs allow to optimize resources, increase technical practice and shorten learning curves, constituting a safe, standardized and validated method of learning for all those trained. Objective: Develop a vascular training program through the elaboration of an end to end anastomosis of a vessel in an experimental model for General Surgery residents. Method: For the development of this training model, an amputated limb was used at the supracondylar level free of medical-legal process. The dissection of the femoral artery was performed, it was divided into two portions and an end to end anastomosis was performed. A system was designed that included the evaluation of the following variables using the OSATS (Objective Structured Assessment of Technical Skills) and Likert scales: 1) manual knot and single stitch; 2) permeability of the anastomosis; 3) symmetry of the stitches; 4) Anastomosis leakage; and 5) total time of the anastomosis. Discussion: Recognizing the advantages of experimental training, a reproducible, standardized, and low cost experimental biological model is proposed. Conclusions: The development of experimental biological models, allows the general surgeon the acquisition of surgical skills and abilities, improving performance during a surgical procedure and reducing risks.
\end{abstract}

Key words: Simulation training. Anastomosis. Anastomotic leak.

\section{Resumen}

Introducción: Los programas de entrenamiento simulado permiten optimizar recursos, aumentar la práctica técnica y acortar curvas de aprendizaje, y constituyen un método seguro, estandarizado y validado de aprendizaje para todos los entrenados. Objetivo: Desarrollar un programa de entrenamiento vascular mediante la elaboración de una anastomosis término-terminal de un vaso en un modelo experimental para residentes de cirugía general. Método: Para el desarrollo de este modelo de entrenamiento se utilizó una extremidad amputada a nivel supracondíleo libre de proceso médico-legal. Se realizó la disección de la arteria femoral, se dividió en dos porciones y se realizó una anastomosis término-terminal. Se diseño un sistema que incluye la evaluación de las siguientes variables utlizando la escalas OSATS (Objetive Structured Assesment of Technical Skills) y Likert: 1) nudo manual y punto simple; 2) permeabilidad de la anastomosis; 3) simetría de los puntos; 4) fuga de anastomosis; y 5) tiempo total de anastomosis. Discusión: Al reconocer las ventajas del entrenamiento experimental, se

\section{Correspondence:}

${ }^{*}$ Christian I. Cruz-Romero

Dr. Balmis, 148 0009-7411/@ 2018 Academia Mexicana de Cirugía. Published by Permanyer. This is an open access article under the terms of the CC BY-NC-ND license (http://creativecommons.org/licenses/by-nc-nd/4.0/). 
propone un modelo biológico experimental reproducible, estandarizado y de bajo costo. Conclusiones: El desarrollo de modelos biológicos experimentales permite al cirujano general la adquisición de habilidades y destrezas quirúrgicas, mejorando el desempeño durante un procedimiento quirúrgico y reduciendo riesgos.

Palabras clave: Simulación. Anastomosis. Fuga de anastomosis.

\section{Introduction}

Surgery has been used as medical treatment throughout times; however, the question on how to obtain surgical skills and abilities remains a topic of intense debate. Medical education in general surgery has gradually moved away from the traditional paradigm of apprenticeship, with this evolution being multifactorial and that, as part of its advances, includes greater training standardization, tighter supervision of working hours and a focus on competence and evaluation of skills".

With graduation of competent surgeons being the goal, surgical educators have recognized the need to improve surgical training efficiency and effectiveness ${ }^{2}$. The general surgery specialty takes 4 years in public or private teaching hospitals of the country and comprises three areas: 1) cognitive, where the diagnostic procedures are substantiated; 2) psychomotor, which points at the essential skills to be developed in the operating room; and 3) affective, where attitudes that will be maintained before patients and their families are learned ${ }^{3}$.

For the teaching-learning process to be efficient, it should focus on meaningful learning, focused rather on the method than on knowledge itself, where the important figure is the student and not the teacher; with an emphasis on learning and not so much on teaching, systematically questioning established knowledge, breaking stereotypes, promoting critical reflection rather than memorization, and students participation in planning and feedback of the program ${ }^{4}$.

Simulation is a technique based on mimicking some process through an equipment that resembles reality with the purpose to improve skills and abilities. In medicine, the use of simulators is essential for patient safety, which forces new teaching processes ${ }^{5}$. Jakimowic ${ }^{6}$ points out the importance of virtual reality models and their advantages, such as objective performance evaluation, interactivity, video availability and didactic training. Simulation has allowed the acquisition of technical skills in traditional open and laparoscopic surgery in postgraduate training ${ }^{7}$. Simulated training programs allow optimizing resources, increase technical practice and shorten learning curves, and constitute a safe, standardized and validated way of learning for all trainees ${ }^{8,9}$.

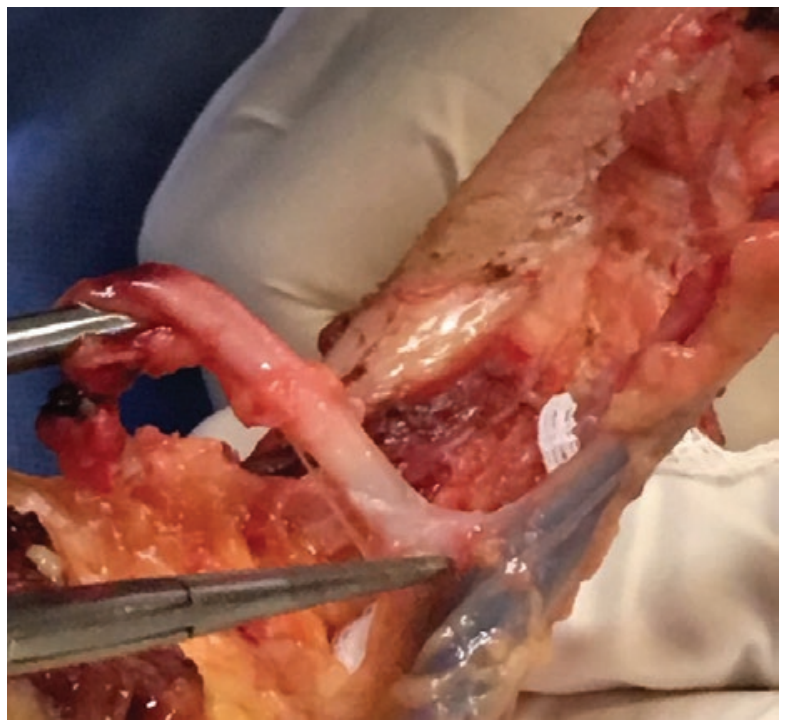

Figure 1. Femoral artery dissection.

The main purpose was to develop a vascular training program that consisted in performing an end-to-end anastomosis of a vessel in an experimental model. Secondary objectives included: 1) developing an instrument to evaluate technical performance, determining its reliability and validity for the performance of vascular anastomoses; and 2) creating a vascular surgery training program for general surgery residents.

\section{Method}

For the development of this training model, a limb amputated at the supracondylar level, free of medicallegal process, was used. Dissection of the femoral artery was performed, it was divided in two portions and an end-to-end anastomosis was carried out. Other essential materials for this practice are needle holders, dissection forceps, Metzembaum scissors, $8 \mathrm{Fr}$ feeding tube, non-absorbable vascular suture (6-0 polypropylene), non-absorbable suture (2-0 silk), gloves, gauze and injectable water.

The model consists of femoral artery dissection in the amputated limb (Fig. 1), carrying out a careful separation until an approximate length of $10 \mathrm{~cm}$ is obtained. Permeability of the blood vessel is verified. The next 


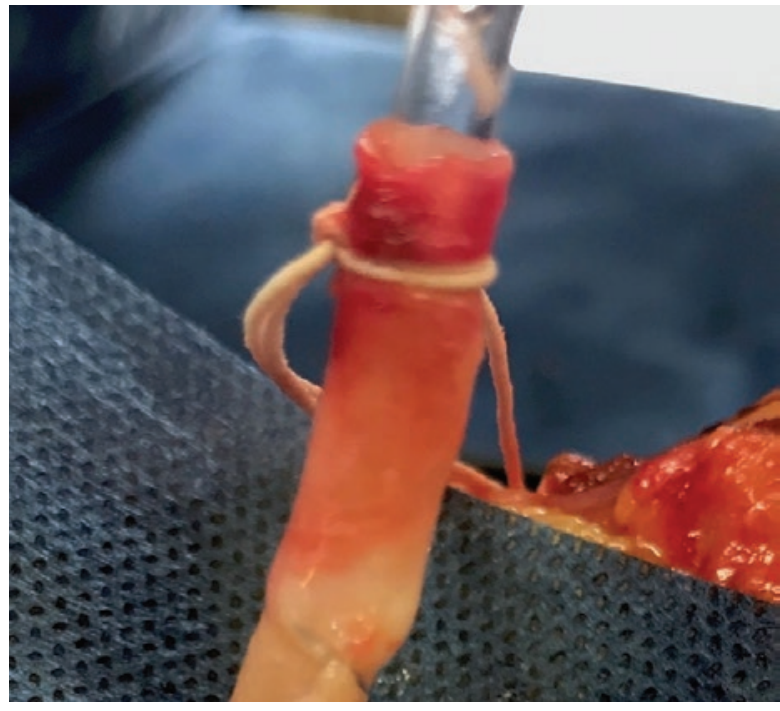

Figure 2. Test for vascular permeability with injectable water.

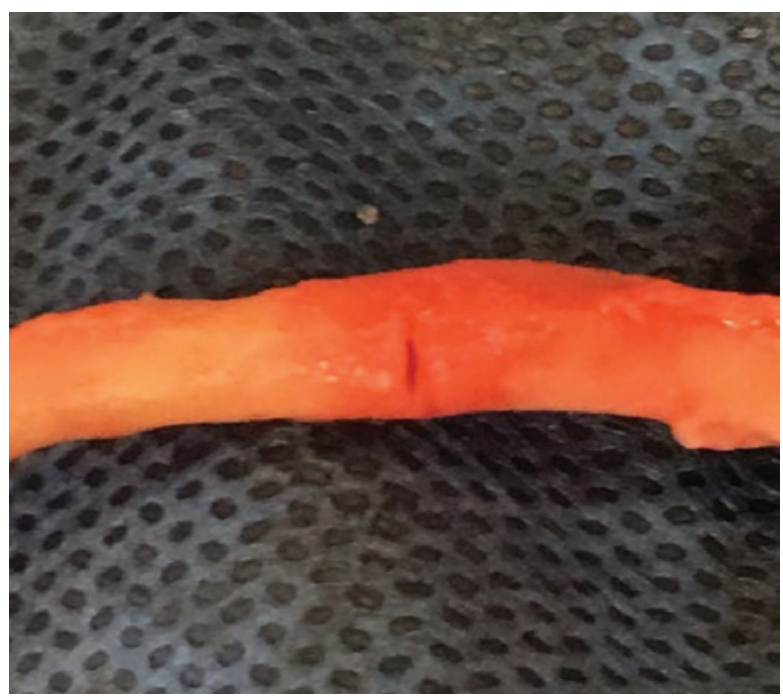

Figure 3. Vascular lesion simulated by cross section.

step is placing the feeding tube at the proximal end, attaching it with a knot (2-0 silk), infusing $10 \mathrm{ml}$ of injectable water and checking for permeability again (Fig. 2). Once the proximal end is secured, a total cross section is made to simulate the vascular lesion with the Metzembaum scissors (Fig. 3). End-to-end anastomosis is carried out with continuous stitches (6-0 vascular polypropylene), anastomosis permeability and tightness are verified by infusing $20 \mathrm{~mL}$ of injectable water through the tube (Fig. 4). Finally, the amount of anastomosis leakage is evaluated by instilling $20 \mathrm{~mL}$ of injectable water at $4 \mathrm{~mL} / \mathrm{s}$, placing at the distal end a container graduated in milliliters and observing the difference between instilled volume and final volume.

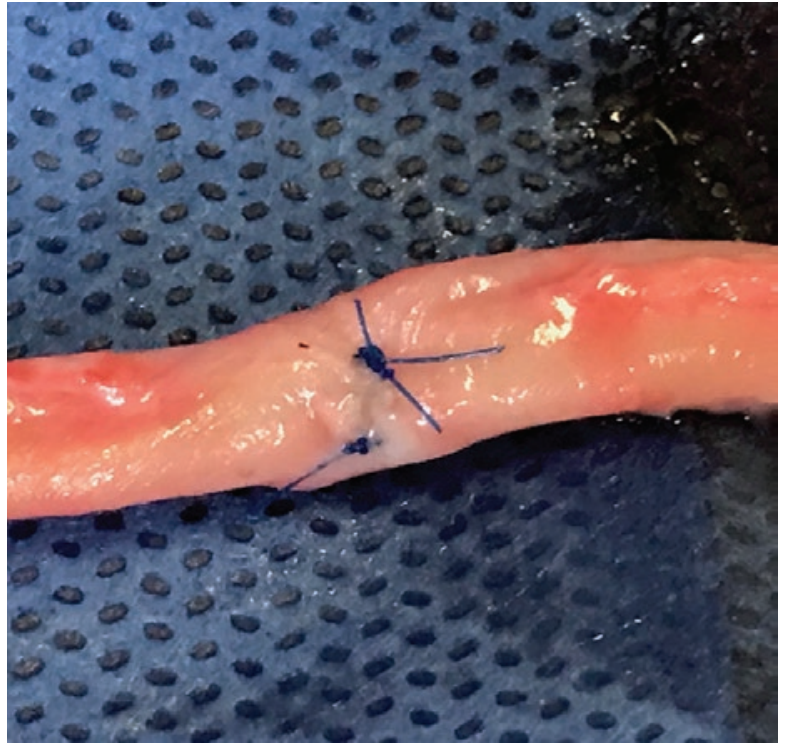

Figure 4. End-to-end anastomosis permeability and tightness.

A practical evaluation system was designed, where the following variables were included when performing the end-to-end anastomosis: 1) manual knot and single stitch; 2) anastomosis permeability; 3) symmetry of stitches; 4) anastomosis leakage of solution; and 5) anastomosis total time. Internationally-validated global assessment scale Objective Structured Assessment of Technical Skills (OSATS) was used (Table 1) ${ }^{7}$. Measuring the attitudes and the degree of agreement of the evaluator is considered important, with a five-point Likert scale being included in our evaluation system: 1) strongly disagree; 2 disagree; 3 ) neither agree nor disagree; 4) agree; and 5) strongly agree.

\section{Discussion}

The training of general surgery residents has been carried out through live demonstrations, always directed by experienced and qualified surgeons. The use of experimental models has been shown to increase surgical skills, with a decrease in risks and surgical time optimization. Recognizing the advantages of experimental training, an experimental, reproducible, standardized and low-cost biological model is proposed.

The acquisition of skills and abilities for achieving competent surgeons is usually heterogeneous, given that there is no objective method to define the level of a skill, and thus the use of models and simulators is highly useful for assessing the capacity in the performance of a surgical procedure ${ }^{10}$.

Simulators have been reported in the literature to be effective during the initial training phase, and have 
Table 1. Objective Structured Assessment of Technical Skills (OSATS) scale for general skills assessment

\begin{tabular}{|c|c|c|c|c|c|}
\hline Score & Respect for tissues & Time and movements & Use of the instrument & $\begin{array}{l}\text { Flow of surgery and } \\
\text { post-planning }\end{array}$ & Knowledge \\
\hline 1 & $\begin{array}{l}\text { Frequent use of } \\
\text { unnecessary force } \\
\text { Damage caused by } \\
\text { inappropriate use of } \\
\text { instruments }\end{array}$ & $\begin{array}{l}\text { Many unnecessary } \\
\text { movements }\end{array}$ & $\begin{array}{l}\text { Repeatedly makes } \\
\text { hesitating movements }\end{array}$ & $\begin{array}{l}\text { Frequently stops } \\
\text { the procedure or requires } \\
\text { discussing the following } \\
\text { steps }\end{array}$ & $\begin{array}{l}\text { Deficient knowledge } \\
\text { and requires } \\
\text { instructions in most } \\
\text { surgical steps }\end{array}$ \\
\hline \multicolumn{6}{|l|}{2} \\
\hline 3 & $\begin{array}{l}\text { Careful manipulation } \\
\text { of tissues, but } \\
\text { occasionally causes } \\
\text { inadvertent harm }\end{array}$ & $\begin{array}{l}\text { Efficient relationship } \\
\text { between time and } \\
\text { movements but makes some } \\
\text { unnecessary movements }\end{array}$ & $\begin{array}{l}\text { Competent use of } \\
\text { instruments but } \\
\text { occasionally is } \\
\text { observed stiff or clumsy }\end{array}$ & $\begin{array}{l}\text { Shows skills } \\
\text { to plan the next steps, with } \\
\text { constant progression of the } \\
\text { process }\end{array}$ & $\begin{array}{l}\text { Know all } \\
\text { important aspects of the } \\
\text { operation }\end{array}$ \\
\hline \multicolumn{6}{|l|}{4} \\
\hline 5 & $\begin{array}{l}\text { Manipulates tissues } \\
\text { properly with } \\
\text { minimal harm }\end{array}$ & $\begin{array}{l}\text { Economy of movements } \\
\text { and maximum } \\
\text { efficiency }\end{array}$ & $\begin{array}{l}\text { Fluid movements } \\
\text { with the instruments and } \\
\text { no clumsiness }\end{array}$ & $\begin{array}{l}\text { Planned course of the } \\
\text { operation in an obvious } \\
\text { way, with effortless flow }\end{array}$ & $\begin{array}{l}\text { Familiarity demonstrated } \\
\text { with all aspects of the } \\
\text { operation }\end{array}$ \\
\hline
\end{tabular}

Source: modified from Martin, et al. ${ }^{7}$

been validated by various studies ${ }^{1,2}$ The use of biological models is still acceptable to explore and improve surgical techniques without compromising patient safety ${ }^{11}$. The main limitation presented by cadaveric biological models is the lack of an imminent hemorrhage, but they are highly useful in the initial acquisition of cognitive and haptic skills that, undoubtedly, provide a benefit when performing a surgical procedure $^{12}$.

\section{Conclusions}

The development of experimental biological models allows the general surgeon to acquire surgical abilities and skills, thus improving performance and reducing risks during surgical procedure. This simulated program proposes an alternative and reproducible method for the development of technical competences and can be incorporated to the program for the training of general surgeons.

\section{Ethical disclosure}

Protection of people and animals. The authors declare that the procedures followed adhered to the ethical standards of the responsible human experimentation committee and are in agreement with the World Medical Association and the Declaration of Helsinki.

Confidentiality of data. The authors declare that no patient data appear in this article.
Right to privacy and informed consent. The authors declare that no patient data appear in this article.

\section{Conflict of interests}

The authors declare that they have no conflicts of interest.

\section{References}

1. Ghaderi I, Fitzgibbons S, Watanabe Y, Lachapalle A, Piage J; Association for Surgical Education Simulation Committee. Surgical skill curricula in American College of Surgeon accredited education institutes: an international survey. Am J Surg. 2016;213:678-86.

2. Badash I, Burtt K, Solorzano C, Carey J. Innovations in surgery simulation: a review of past, current and future techniques. Ann Transl Med. 2016;4:453

3. Córdoba D, Ojeda G, Sapién J, Rosas BJ, Morales MP. La especialidad de cirugía general: experiencias de residentes. Rev Espec Médico-Quirúrgicas. 2009;14(2):79-82.

4. Vega J, Zaldívar G, Ávila J, Vega J, Romero J. El cirujano científico y la enseñanza de la cirugía en México. Segunda parte: La enseñanza de la cirugía en el postgrado y educación médica continua del cirujano. Cirujano General. 2004;26(4):330-6.

5. Carrasco Rojas JA, García CB, Carrasco JA. Utilización de simuladores en la educación quirúrgica. Cirujano General. 2013;35(Supl 1):S62-5.

6. Jakimowicz J. Simulación en cirugía, ¿dónde estamos y a dónde llegaremos? Cir Cir 2011;79:44-49.

7. Martin JA, Regehr G, Reznick R, MacRae H, Mur-naghan J, Hutchison C, et al. Objective structured assessment of technical skill (OSATS) for surgical residents. Br J Surg. 1997;84:273-8

8. Van Nortwick SS, Lendvay TS, Jensen AR, Wright AS, Horvath KD, Kim S. Methodologies for establishing validity in surgical simulation studies. Surgery. 2010;147:622-30.

9. Reznick RK, MacRae H. Teaching surgical skills - changes in the wind. N Engl J Med. 2006;355:2664-9.

10. Gallagher AG. Metric-based simulation training to proficiency in medical education: what it is and how to do it. Ulster Med J. 2012:81:107-13.

11. Shamin K, Ahmed K, Gavazzi A. Development and implementation of centralized simulation training: evaluation of feasibility, acceptability and construct validity. BJU Int. 2013;111:518-23.

12. Sutton E, Billeter A, Druen D, Roberts H, Rice J. Development of a human cadaver model for training in laparoscopic donor nephrectomy. Clin Transplant. 2017;31(6). doi: 10.1111/ctr.12979. Epub 2017 Apr 24. 